\title{
Antidumping Law as a Collusive Device
}

\author{
Maurizio Zanardi* \\ Boston College
}

November 2000

\begin{abstract}
Empirical evidence for the United States shows that many antidumping petitions are withdrawn before the International Trade Commission and the International Trade Administration complete their investigations. Prusa (1992) argues that petitions are used by domestic industries to threaten and induce foreign industries into a collusive agreement exonerated from antitrust concerns because of US trade laws. In his model, all antidumping petitions should be withdrawn, which is not the case. This paper provides a model in which only some petitions are withdrawn and Prusa's result is just a special case. The decision to withdraw a petition depends on two key parameters: the coordination cost and the bargaining power of domestic and foreign industries. A new dataset is constructed to test the theoretical model on the US experience for the period 1980-1992. The econometric analysis supports the theoretical conclusions of the model. This finding is consistent with the hypothesis that the antidumping law is used as a collusive device.
\end{abstract}

Keywords: Antidumping; Bargaining cost; Collusion; Coordination cost; Withdrawn petitions

JEL classification: F13; D43

\footnotetext{
${ }^{*}$ I would like to thank Jim Anderson, Hideo Konishi, and Serena Ng for their suggestions and support, and Thomas Prusa for providing some of the data used in this paper. Suggestions from seminar participants at Boston College, Università Cattolica (Milan), Midwest International Economics Meetings in Minneapolis, and the Southeast Theory and International Economics Meetings in Houston are also acknowledged. Any remaining errors are solely mine. Contact information: Department of Economics, Boston College, Chestnut Hill - MA 02467, USA. E-mail: zanardi@bc.edu
} 
"But though the law cannot hinder people of the same trade from sometimes assembling together, it ought to do nothing to facilitate such assemblies; much less to render them necessary." Adam Smith (1776).

\section{Introduction}

The use of the antidumping ( $\mathrm{AD}$ ) law has exploded in the US and spread from there to many other countries. For example, the World Trade Organization reports that a total of 291 AD petitions were filed in the period July 1998-June 1999 as opposed to 173 for the same period in 1980-81. The cumulative effect of AD cases is large. For example, Gallaway et al. (1999) estimate that the collective net cost of antidumping and countervailing duty orders (a less used law which offsets export subsidies) was around $\$ 4$ billion in 1993 for the US. This amount is larger than the cost of any US trade restraint policy with the exception of the Multi-Fibre Arrangement.

In US trade law, dumping "is defined as selling a product in the United States at a price which is lower than the price for which it is sold in the home market, after adjustments for differences in the merchandise, quantities purchased, and circumstances of sale." ${ }^{1}$ When AD petitions are accepted by the International Trade Commission (ITC) and the International Trade Administration (ITA), AD duties are imposed that eliminate the effects of dumping. However, a hidden cost of $\mathrm{AD}$ law may be signaled by withdrawn petitions, i.e. cases which are settled between foreign and domestic firms prior to a final determination of the case. US trade law fosters price-fixing by foreign and domestic firms by exempting them from US competition policy. In particular, the Noerr-Pennington doctrine exonerates firms from prosecution under the antitrust law for petitions filed with anticompetitive goals. The share of petitions withdrawn is about $20 \%$, too large to ignore as chance. Moreover, the trade suppressing effects of $\mathrm{AD}$ cases are about the same whether the case ends in an $\mathrm{AD}$ duty or a withdrawn petition: prices rise and quantities fall. This observation

\footnotetext{
${ }^{1}$ Statement of Administrative Action on the Uruguay Round (1994), page 150.
} 
does not only hold for petitions withdrawn because of formal agreements reached under the auspices of the Department of Commerce (suspension agreement), but in general for withdrawn petitions. Hence, the concern that some forms of collusion are attained in a more general setting with the AD law serving as the collusive device.

AD petitions may be used by domestic industries to threaten and induce foreign industries into an arrangement. The threat is credible because if an agreement is not achieved, the investigation proceeds and duties are levied in case of an affirmative decision. Therefore, the AD law not only facilitates collusion at a domestic level by inducing domestic producers to coordinate, but because of the Noerr-Pennington exemption, it enhances collusion at an international level.

Prusa (1992) offers a model of withdrawn petitions. The threat of an AD duty induces foreign firms to bargain over price fixing arrangements with domestic firms. With the bargain, both sides can benefit. Prusa's conclusion, that industries would always prefer to withdraw a petition and reach a private agreement, is very strong. If taken seriously, it implies that we should not observe any decision by the ITC and ITA because industries would always withdraw petitions. Evidence tells us that this is not true. Hence, a modification of the model by Prusa is needed to obtain less strict implications where only some petitions are withdrawn.

This paper shows that the optimal choice between withdrawing a petition and waiting for the federal agencies' decisions depends on two key parameters: the coordination cost and the bargaining power of the domestic and foreign industry. The econometric analysis tests these conclusions on the US experience using a unique dataset constructed from the reports published by the ITC and the ITA for the petitions filed in the period 1980-1992. The results support the conclusions of the theoretical model. In particular, the variables used as indicators of coordination costs and bargaining powers are able to explain the choice of whether or not to withdraw an AD petition. These findings are consistent with the hypothesis that the antidumping law is used as a collusive device. 
On the theoretical side, this paper shares the spirit of previous analyses (see for example Anderson, 1992; Staiger and Wolak, 1989) that highlight the strategic behavior of firms once AD laws are implemented. Veugelers and Vandenbussche (1999), a related theoretical study, analyze the possibility that the European AD law leads to collusion among firms. Their emphasis is on the conditions that sustain different forms of collusion depending on the commission's decision to impose duties or price undertakings. Although in the same spirit, this paper focuses on the firms' decision without explicitly assigning a role to the policy maker. On the empirical side, this study investigates the decision to withdraw a petition by characterizing the domestic and foreign industries. Hence, it complements some of the results of Prusa (1991) about the determinants of ITC decisions.

The remainder of the paper is organized as follows. In Section 2, a background of the US AD law and implied procedures is provided. Some descriptive statistics are also given to quantify the phenomenon. The theoretical model that leads to the possible bargaining outcome and the withdrawal of a petition is analyzed in Section 3. Section 4 is dedicated to the empirical analysis and Section 5 concludes.

\section{Background on Antidumping Procedures}

The US law requires an AD petition to be filed with the ITC and the ITA at the Department of Commerce at the same time. ${ }^{2}$ The former agency is responsible for determining if the domestic industry is materially injured or threatened with material injury by reason of the imports considered. The latter has to ascertain if imports are being, or are likely to be, sold at less than fair value. The investigation develops into a preliminary and a final determination by both agencies. AD duties are imposed if both agencies reach an affirmative outcome in the final determination of the investigation. However, a negative preliminary determination by the ITA does not end the inquiry

\footnotetext{
${ }^{2}$ A petition can be self-initiated by the Department of Commerce but that rarely happens.
} 
while a negative preliminary finding by the ITC does conclude the investigation.

The phases of the examination by the these agencies are subject to strict time limits so that an AD petition cannot take more than 310 days before being resolved. ${ }^{3}$ Moreover, a preliminary determination by the ITC, which ends the case if negative, must come within 45 days from the initial act of filing the petition.

An AD case has three possible outcomes: a negative determination, an affirmative determination with duties being levied, or the withdrawal of the petition. The focus of this paper is on the petitions that are withdrawn and Table 1 gives an idea of the relevance of the phenomenon. Withdrawn petitions represent $19.19 \%$ of all petitions in the nineteen years from 1980 until 1998. However, this share varies considerably over time reaching a maximum of $56.76 \%$ in 1984 . The table indicates a downward trend in AD cases during the beginning of the 1990s, but we may be at the turning point of this series starting in 1998 since 54 petitions were filed in 1999 and 30 by the end of October $2000 .^{4}$

Geographically, the targets of most petitions are split in two groups: Asian and European countries. Japan, China, South Korea, and Taiwan dominate the first group while Germany, Italy, France, and the United Kingdom are the prominent examples for Europe. Canada and Brazil also account for important shares of total cases.

The steel industry files the most petitions. Other frequent filing industries include chemicals, food, and textiles and apparel. Overall, there is a wide variety of commodities currently subject to AD duties: steel pipe and tube, cement, pencils, aspirin, and fresh garlic are just a few examples.

\footnotetext{
${ }^{3}$ Complicated and extended petitions have a 420 day limit.

${ }^{4}$ Recent years not included in Table 1 because not all the petitions have reached the final stage.
} 


\section{The Model}

This Section models the competition among domestic and foreign firms and the response of domestic firms to dumping behavior. The basic setup is taken from Prusa (1992), but significant extensions are made to his original framework in order to explain why only some petitions are withdrawn. His results correspond to a special case of the following model.

The market of interest consists of $n$ domestic risk-neutral firms and $n^{*}$ foreign risk-neutral firms which produce differentiated products and compete on prices (in the following, an asterisk always denotes foreign variables). Bertrand competition among domestic and foreign firms determines the status-quo equilibrium. ${ }^{5}$ Given this initial equilibrium, Figure 1 illustrates the timing of events and the possible alternative strategies.

In the first stage, domestic firms can join together and act as a single industry in filing an AD petition. ${ }^{6}$ If a petition is not filed, the Bertrand equilibrium will persist. In the second stage, the domestic industry can either withdraw the petition through an agreement or leave the ITC and ITA to proceed to the final determination. If the petition is not withdrawn, an affirmative determination will occur with an exogenous probability $\rho$. Under this scenario, the foreign industry will pay duties, as determined by federal agencies, on the quantity exported. In the event of a negative outcome of the investigation (probability $1-\rho$ ), the industries will earn Bertrand profits as if the petition was never initiated.

\subsection{The Bertrand Equilibrium}

Assume symmetry in the demand and cost functions among domestic firms and among foreign firms. Each domestic firm $i$ faces demand curve $q_{i}\left(P, P^{*}\right)$ where $P=\left(p_{i}\right)_{i=1}^{n}$

\footnotetext{
${ }^{5}$ The model can be reformulated in a Cournot framework and the results do not change. Joint monopoly profits higher than joint Nash profits is the condition that guarantees this robustness.

${ }^{6}$ Alternatively, they can file separately but coordinate on timing; this distinction is irrelevant.
} 
is the domestic price vector, and $P^{*}=\left(p_{j}^{*}\right)_{j=1}^{n^{*}}$ is the foreign price vector. Similarly, each foreign firm $j$ faces demand curve $q_{j}^{*}\left(P^{*}, P\right)$. It is assumed that each firm's demand function is continuous, bounded, nonincreasing and concave in its own price and nondecreasing in the other firms' prices, and twice continuously differentiable. Moreover, it is assumed that if all firms raise their prices by an equal amount, all firms having positive demand will observe a decrease in their demand. ${ }^{7}$

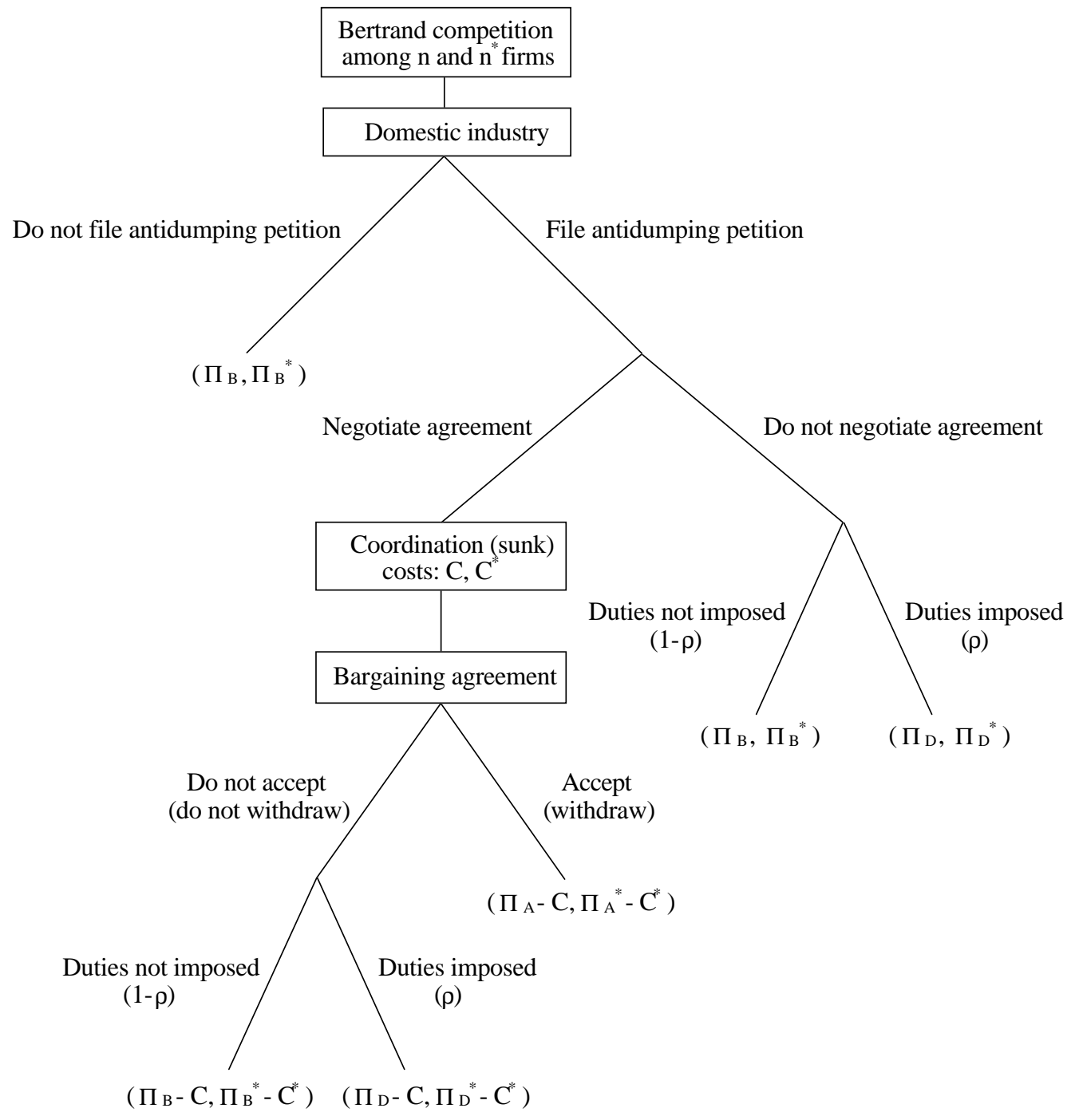

Figure 1: Sequence of events

\footnotetext{
${ }^{7}$ Formally, $\sum_{k=1}^{n} \frac{\partial q_{i}\left(P, P^{*}\right)}{\partial p_{k}}+\sum_{h=1}^{n^{*}} \frac{\partial q_{i}\left(P, P^{*}\right)}{\partial p_{h}^{*}}<0$ for $i=1, \ldots, n$, and $\sum_{k=1}^{n} \frac{\partial q_{j}^{*}\left(P^{*}, P\right)}{\partial p_{k}}+\sum_{h=1}^{n^{*}} \frac{\partial q_{j}^{*}\left(P^{*}, P\right)}{\partial p_{h}^{*}}<0$ for $j=1, \ldots, n^{*}$. These conditions are not stringent and can be easily satisfied (see Ottaviano and Thisse, 1999).
} 
Domestic firm $i$ chooses $p_{i}$ in order to maximize its profit given by

$$
\pi_{i}=\pi\left(p_{i}, P_{-i}, P^{*}\right)=p_{i} \cdot q_{i}\left(p_{i}, P_{-i}, P^{*}\right)-T C\left(q_{i}\left(p_{i}, P_{-i}, P^{*}\right)\right)
$$

where $P_{-i}=\left(p_{i^{\prime}}\right)_{i^{\prime} \neq i}$, and $T C$ is the firm's convex cost function. Similarly, foreign firm $j$ chooses $p_{j}^{*}$ in order to maximize

$$
\pi_{j}^{*}=\pi^{*}\left(p_{j}^{*}, P_{-j}^{*}, P\right)=p_{j}^{*} \cdot q_{j}^{*}\left(p_{j}^{*}, P_{-j}^{*}, P\right)-T C^{*}\left(q_{j}^{*}\left(p_{j}^{*}, P_{-j}^{*}, P\right)\right)
$$

where $P_{-j}^{*}=\left(p_{j^{\prime}}^{*}\right)_{j^{\prime} \neq j}$, and $T C^{*}$ is the firm's convex cost function.

The first order conditions for profit maximization are (arguments of the functions omitted for notational simplicity):

$$
\begin{array}{rl}
q_{i}+p_{i} \frac{\partial q_{i}}{\partial p_{i}}-\frac{\partial T C}{\partial q_{i}} \cdot \frac{\partial q_{i}}{\partial p_{i}}=0 & i=1, \ldots, n \\
q_{j}^{*}+p_{j}^{*} \frac{\partial q_{j}^{*}}{\partial p_{j}^{*}}-\frac{\partial T C^{*}}{\partial q_{j}^{*}} \cdot \frac{\partial q_{j}^{*}}{\partial p_{j}^{*}}=0 & j=1, \ldots, n^{*} .
\end{array}
$$

Equations (3) and (4) implicitly describe the best response functions. The solution of the above system of $\left(n+n^{*}\right)$ equations gives the Bertrand equilibrium. The conditions stated above guarantee existence and uniqueness of the Bertrand equilibrium. ${ }^{8}$ Let the Bertrand equilibrium price vector be $\left(P_{B}, P_{B}^{*}\right)$; each domestic firm enjoys positive profits $\pi_{i B}=\pi\left(P_{B}, P_{B}^{*}\right)$ and each foreign firm enjoys positive profits $\pi_{j B}^{*}=\pi^{*}\left(P_{B}^{*}, P_{B}\right)$. This is the equilibrium that persists if a petition is not filed.

\subsection{The Filing Decision}

By filing the petition, domestic firms act as a single player. For this reason, the analysis can be carried on by referring to a domestic industry and a foreign industry instead of single firms. Industries are defined as the average of firms, and capital letters denote industry level variables. With a little abuse of notation, but gaining in simplicity, let industry profits be $\Pi\left(P, P^{*}\right)$ and $\Pi^{*}\left(P^{*}, P\right)$.

\footnotetext{
${ }^{8}$ See Friedman (1977) for a detailed discussion of these conditions.
} 
With a probability $(1-\rho)$ the federal agencies do not impose AD duties, and profits remain at the Bertrand equilibrium as if the petition was never filed: $\Pi_{B}$ and $\Pi_{B}^{*}$. In case of an affirmative outcome (probability $\rho$ ), the ITC and the ITA order the foreign industry to charge $P_{D}^{*}$, and to pay a duty $d$ on the goods exported $\left(Q_{D}^{*}\right)$. Foreign producers will only collect $P_{B}^{*}$ by selling each unit, the duty representing the difference between the price foreign firms were supposed to charge $\left(P_{D}^{*}\right)$ and the price set in the Bertrand equilibrium $\left(P_{B}^{*}\right): d=\left(P_{D}^{*}-P_{B}^{*}\right)$. The domestic industry raises its price to $P_{D}$ according to its best response function. As a result, consumers pay $P_{D}^{*}$ for the foreign good and $P_{D}$ for the domestic good. Profits in case of AD duties are $\Pi_{D}=\Pi\left(P_{D}, P_{D}^{*}\right)$ and $\Pi_{D}^{*}=\Pi^{*}\left(P_{D}^{*}, P_{D}\right)-d Q_{D}^{*}\left(P_{D}^{*}, P_{D}\right)$. Since the domestic industry is on its best response function and the foreign industry sells less at the same price, the following result obtains:

Lemma $1 \Pi_{D}^{*}<\Pi_{B}^{*}$ and $\Pi_{D}>\Pi_{B}$.

Proof: see Appendix A.

With the probability $\rho$ of an affirmative decision exogenous and known, expected profits if industries do not consider the option of an agreement are respectively:

$$
\begin{gathered}
\Pi^{e}(\rho)=\rho \Pi_{D}+(1-\rho) \Pi_{B} \\
\Pi^{* e}(\rho)=\rho \Pi_{D}^{*}+(1-\rho) \Pi_{B}^{*} .
\end{gathered}
$$

Lemma 1 implies $\Pi^{e}>\Pi_{B}$ for any $\rho>0$. In turn, this assures that filing an AD petition is a dominant strategy for the domestic industry. In fact, the option of not negotiating is always available so that the expected profits $\Pi^{e}$ are always guaranteed. Therefore, whatever outcome the petition will lead to, its expected value is better than the Bertrand equilibrium that prevails if the petition is not filed. ${ }^{9}$

\footnotetext{
${ }^{9}$ For simplicity, the cost to file the petition is assumed to be zero. If positive, the previous conclusion would follow if the probability $\rho$ is sufficiently high to assure that $\Pi^{e}>\Pi_{B}+$ (filing cost). The empirical exercise of this paper considers only petitions that have been actually filed. The consideration of a filing cost is therefore irrelevant for the empirical specification.
} 
It is useful to look at the graphical representation of the equilibrium in the profit space. Let the profit possibilities frontier (PPF) be defined as the locus of maximum profits attainable by the two industries and non-negativity constraints. Its analytical formulation is given by:

$$
\begin{gathered}
\max _{P, P^{*}} \Pi\left(P, P^{*}\right) \\
\text { s.t. } \Pi^{*}\left(P^{*}, P\right) \geq \bar{\Pi}^{*}, \Pi^{*}>0, \bar{\Pi}>0
\end{gathered}
$$

where $\bar{\Pi}^{*}$ stands for any possible value of foreign profits. The PPF is downward sloping and concave. It is downward sloping because the profits of one industry can be increased only by decreasing the profits of the other industry. It is concave since each industry's profit function is assumed concave.

Figure 2 is a graphical representation of the model at the industry level. The Bertrand equilibrium, $B$, is an interior point of the set bounded by the PPF. $M$ and $M^{*}$ correspond to the points of monopoly profit for each industry. The equilibrium outcome of an affirmative decision is point $D$, which is given by $\Pi_{D}$ and $\Pi_{D}^{*}$. The segment that links point $B$ and $D$ represents all the possible expected profits for any probability $\rho$.

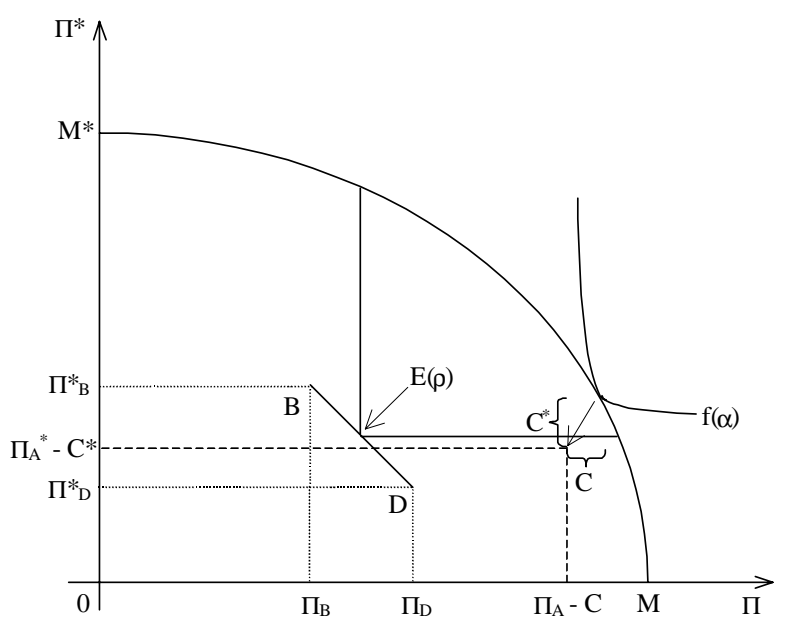

Figure 2: Equilibria in profit space 


\subsection{The Bargaining Stage}

Both the domestic and the foreign industry have an incentive to negotiate an agreement because it can increase their profits with respect to the expected values in (5) and (6). The bargaining stage allows industries to collude and increase their profits over the expected profits. Both sides can gain by settling the AD case.

Domestic firms, and correspondingly foreign firms, must reach a common position before going to the bargaining stage with the opponent. This coordination is essential if the negotiating table is to be reached. $C$ and $C^{*}$ capture these sunk costs. It is reasonable to think of these costs as increasing in the number of firms: coordination requires firms to find a common strategy and this task is more difficult, the larger the number of firms. ${ }^{10}$

When the two industries bargain, they may enjoy different bargaining powers. Therefore, let the bargaining power of the domestic industry be $0<\alpha<1$. Then, $(1-\alpha)$ represents the bargaining power of the foreign industry.

Having defined the elements of the negotiating table, a bargaining mechanism has to be chosen. The Nash bargaining solution provides a simple and intuitive way to solve this kind of problem. Originally derived as the unique solution for a set of axioms (Nash, 1950), it can be justified as the outcome of a noncooperative game (Rubinstein, 1982). In its general formulation with asymmetric bargaining powers, the solution to the industries' problem is found as follows:

$$
\max _{P, P^{*}}\left[\Pi\left(P, P^{*}\right)-C-\left(\Pi^{e}(\rho)-C\right)\right]^{\alpha}\left[\Pi^{*}\left(P, P^{*}\right)-C^{*}-\left(\Pi^{* e}(\rho)-C^{*}\right)\right]^{1-\alpha} .
$$

Once the industries reach the negotiating table, the effort spent to collude, namely $C$ and $C^{*}$, is a sunk cost. Therefore, industries want to maximize the difference between net profits and the payoffs they get in case an agreement is not found. These payoffs are given by expected profits minus coordination costs since if a settlement is not reached, the ITC and ITA will make their own determinations.

\footnotetext{
${ }^{10} \mathrm{An}$ information argument provides a way to think about these costs: they are increasing in the number of messages that firms must exchange in order to collude.
} 
The solution to the game is unique because the bargaining set, namely the set of profits higher than the expected ones and bounded by the PPF, is convex. Net profits from the agreement are $\Pi_{A}\left(P_{A}, P_{A}^{*}\right)-C$ and $\Pi_{A}^{*}\left(P_{A}, P_{A}^{*}\right)-C^{*}$. Note that the solution to the game in (8) implies net profits higher than expected profits minus costs. Therefore, if the bargaining stage is reached, the bargaining solution will always be preferred.

As it appears from the decision tree in Figure 1, each industry decides about the opportunity of a negotiated agreement by comparing its payoffs with and without the option of the settlement. If an agreement is not pursued, industries' expected profits are $\Pi^{e}$ and $\Pi^{* e}$. Backward induction of the bargaining outcome makes it worth pursuing if $\Pi_{A}-C>\Pi^{e}$ and $\Pi_{A}^{*}-C^{*}>\Pi^{* e}$. These same conditions guarantee that the petition will be withdrawn.

The conditions for the withdrawal of the petition yield the following:

Proposition 1 Suppose the bargaining problem is convex. For each $\alpha$ and $\rho$, there exist critical values $\widetilde{C}(\alpha, \rho)$ and $\widetilde{C}^{*}(\alpha, \rho)$ such that if $C \leq \widetilde{C}$ and $C^{*} \leq \widetilde{C}^{*}$, the petition will be withdrawn. Moreover, $\frac{\partial \widetilde{C}}{\partial \alpha}>0, \frac{\partial \widetilde{C}^{*}}{\partial \alpha}<0$.

Proof: see Appendix A.

Proposition 1 says that the higher the bargaining costs, the lower the probability of the petition being withdrawn, for a given bargaining power and probability $\rho$. There is a threshold value for both coordination costs that eliminates the possibility of bargaining an agreement because at least one player would be worse off under the settlement. However, the critical values $\widetilde{C}$ and $\widetilde{C}^{*}$ are not constant. They depend on the bargaining power since it determines how profits from collusion are split between the domestic and foreign industry.

The critical values also depend on the exogenous probability $\rho$ because it influences the outside option of the game. The signs of the derivatives with respect to $\rho$ are ambiguous as they depend on the particular shape of the PPF. ${ }^{11}$ In particular, the

\footnotetext{
${ }^{11}$ See the proof of Proposition 1 in Appendix A.
} 
derivative $\frac{\partial \widetilde{C}}{\partial \rho}$ is more likely to be negative, the steeper the PPF. Intuitively, the steeper the PPF, the smaller the increase in the bargained profit for the domestic industry. In the very special case of a linear PPF parallel to the segment $\overline{B D}$ in Figure 2, the derivatives of the critical values with respect to $\rho$ are zero because the change in the bargained profits is exactly offset by the change in the expected profits brought by the change in the probability.

The intuition behind the result in Proposition 1 can be visualized by the graphical representation of the Nash bargaining game. Note that the game in (8) can be simplified to

$$
\max _{P, P^{*}}\left[\Pi\left(P, P^{*}\right)-\Pi^{e}(\rho)\right]^{\alpha}\left[\Pi^{*}\left(P, P^{*}\right)-\Pi^{* e}(\rho)\right]^{1-\alpha} .
$$

Therefore, the solution can be illustrated in Figure 2 without considering that the PPF and conflict payoffs $\left(\Pi^{e}, \Pi^{* e}\right)$ shift because of the coordination costs. ${ }^{12}$ Given this simplification, the asymmetric game is solved considering the tangency between the boundary of the bargaining set (PPF) and a hyperbola asymptotic to the conflict payoffs. The hyperbola is symmetric for equal bargaining powers between the domestic and foreign sector $(\alpha=.5)$, and becomes more and more skewed toward the $x-$ axis for increasing values of $\alpha$.

In Figure 2, $E(\rho)$ represents the expected (conflict) payoffs $\left(\Pi^{e}(\rho), \Pi^{* e}(\rho)\right)$ and $f(\alpha)$ emphasizes that the hyperbola depends on the bargaining power. The graph illustrates a case where the domestic industry has a much larger bargaining power. Consequently, the foreign industry's profits in the agreement do not increase much with respect to the expected profits. In the graph, the coordination cost of the foreign sector $\left(C^{*}\right)$ is such that the foreign industry is worse off with the agreement than without. Backward induction of this consequence makes the agreement impossible. Hence, the domestic industry does not withdraw the petition, but waits for the federal agencies' decision.

\footnotetext{
${ }^{12}$ The graphical representation of (8) implies moving the origin by a distance determined by the coordination costs.
} 
The graph shows that it is not the bargaining power or the coordination cost per se that determines the result. With the same costs, a lower bargaining power for the domestic industry would have made an agreement possible and thus caused the withdrawal of the petition (i.e. $\frac{\partial \widetilde{C}^{*}}{\partial \alpha}<0$ ). In the same way, a lower coordination cost for the foreign industry would have permitted a collusive outcome even if the bargaining powers were the same.

The result that not all the petitions are withdrawn stems from the modifications made to the model proposed by Prusa (1992). His setup corresponds to the special case where there are no costs of coordination, the domestic and foreign industries enjoy the same bargaining power $(\alpha=.5)$, and there is only one domestic and one foreign firm $\left(n=1, n^{*}=1\right)$. In his setting, industries always gain by withdrawing a petition and reaching an agreement since the Nash bargaining solution occurs in the middle of the arc of the PPF delimited by the continuous lines in Figure 2. Even in the extreme case of $\rho$ equal to one, the foreign industry prefers to settle because it can bargain over the duties. In this sense, Prusa's model suggests that we should always observe agreements between the conflicting parties. On the contrary, a significant share of petitions are not withdrawn even though only half of them will end with AD duties being levied. The present model can explain this evidence arguing that petitions are withdrawn when a collusive agreement is reached between the domestic and foreign industry.

\section{The Empirical Analysis}

The relevance of the theoretical framework developed in the previous Section can be assessed empirically. Proposition 1 highlights the fact that coordination costs and bargaining powers are crucial elements in reaching a collusive agreement. In particular, the probability of withdrawing the petition is negatively related to the coordination cost, for a given bargaining power. Therefore, making use of a panel 
dataset that contains petitions filed in the United States in the period 1980-1992, the probability of withdrawing a petition is modeled as:

$$
\operatorname{Prob}(Y=1)=F\left(\beta^{\prime} X\right)+\varepsilon
$$

where $Y$ assumes the value of 1 when a petition is withdrawn and 0 when it is not, $F(\cdot)$ is the standard normal distribution, and $\varepsilon$ is the error term. ${ }^{13}$ Observations are not independent since the same industry repeatedly files petitions. For this reason, robust standard errors are calculated using the White estimator. Moreover, allowing for dependence only within 4-digit SIC industry definitions or within each case does not produce any significant difference in the estimated coefficients (case refers to the complaint brought by the US industry as a whole, even if the ITC institutes different petitions for each involved foreign country).

Specifically, $X$ includes a constant, indicators of costs of coordination, indicators of bargaining power, and control variables. A positive sign is expected for the variables representing the bargaining power of the industry with possibly nonlinear effects since a very high bargaining power should lead to a nonwithdrawal. On the contrary, the variables representing the costs of coordination should enter with a negative sign. ${ }^{14}$

The costs of coordination are clearly related to the number of producers in the market. Natural candidates to represent these costs are various concentration indexes: higher levels of concentration facilitate collusion, alleviating the coordination problem firms have to solve. For the domestic industry, the total cost of coordination is also increasing in the number of foreign countries involved since a petition can be simultaneously filed against producers from different countries. However, the average cost may be either increasing or decreasing. The number of countries involved in a case can be a relevant explanatory variable.

In the same way, the number of producers, number of importers, and number of filers of the petition can be used. Trade associations and ad hoc committees formed

\footnotetext{
${ }^{13}$ There is no noticeable difference between estimating probit or logit regressions.

${ }^{14}$ Positive or negative signs refer to the very concept of power and cost, but the regressors may be expressed in such a way (index, change over time, etc.) that the expected sign is the opposite.
} 
in order to file a petition should improve the coordination task of domestic firms, and a dummy variable captures this effect.

There is no theory of bargaining power, apart from Rubinstein's identification of it with relative discount rates. In practical terms, economists think that bargaining powers depend on the industry's reputation or on other factors as well such as impatience and uncertainty. An important channel that can affect the bargaining power of the domestic industry is its pressure in the political arena: pressure to obtain import relief actions in the form of quotas, VERs, or other government supervised agreements. This pressure improves the relative position of the domestic industry because foreign firms would prefer to settle.

Employment and the number of previously filed petitions are potentially good indicators of bargaining power. More employees lead to stronger political influence because the injury from unfair imports would negatively affect more workers. The use of employment as a political variable is consistent with the literature that excludes employment as a measure of industry size and therefore of concentration (see Finger et al., 1982; Prusa, 1991). Analogously, filing numerous petitions increases the "visibility" of the industry in the political arena giving a signal of a tough player.

Among the control variables, nominal exchange rate and trade deficit control for the documented countercyclical nature of trade barriers. Related to the AD phenomenon, dummy variables for particular groups of countries are relevant. On one hand, European Union and OECD countries may enjoy a preferential treatment for major trade partners. On the other hand, non market economies are more easily found guilty of dumping because of difficult comparisons of market prices. One more dummy variable captures the fact that from 1984 the AD law requires the ITC to cumulate imports from different countries when determining injury, a modification known to influence the decision to file a petition (see Hansen and Prusa, 1996).

One last control variable is a steel sector dummy variable. In fact, many withdrawn petitions pertain to this industry. It is important to see if the phenomenon under 
investigation is sector specific or if it is an occurrence common to manufacturing industries in general.

\subsection{Data}

The empirical study is limited to the period 1980-1992. The pre-1980 experience is not comparable because the Treasury Department, instead of the Department of Commerce, was in charge of the investigation about the less-than-fair-value pricing behavior. Availability of data from the Census Bureau dictates the choice of 1992 .

The newly constructed dataset is composed of data collected at two different levels of aggregation. ${ }^{15}$ A first source is the US Census Bureau with domestic aggregate data at the 4-digit SIC level. The second source of data is provided by the reports published by the ITA and the ITC. The information in the reports for each petition is quite valuable and this paper is the first to make extensive use of this source, in particular, for data on foreign industries. For example, Prusa in a series of papers, Baldwin and Steagall (1994), and De Vault (1993) use some of the information contained in the petitions but only to identify the good under investigation or to describe the domestic industry and the outcome. In contrast, this paper relies on this source to characterize the domestic and foreign industry.

Over the thirteen years included in the sample, 640 petitions have been filed. The analysis is limited to the manufacturing sector since lack of data forces to drop petitions pertaining to the agricultural and mining sectors. Petitions withdrawn for reasons such as inadequate filing, re-filed soon after, not accepted by the ITA but clearly not withdrawn because of agreements are dropped. A few outliers have also been excluded. ${ }^{16}$ In the end, the dataset contains 588 petitions: $19.22 \%$ withdrawn, $40.64 \%$ negative, and $40.14 \%$ affirmative.

From descriptive statistics, interesting regularities emerge. Industries involved in

\footnotetext{
${ }^{15}$ See Appendix $\mathrm{B}$ for a complete description of the data.

${ }^{16}$ Ten observations are eliminated because the values of some variables are from 10 to 75 times larger than the mean.
} 
the withdrawal of petitions are more homogeneous if compared to industries that obtained affirmative and negative outcomes for their petitions. In fact, the standard deviation of all variables except employment is lower. This finding is consistent with the theoretical model. Total employment is on average $50 \%$ higher for withdrawn petitions. This is in line with the interpretation of employment as an indicator of political influence and therefore bargaining power. Following this interpretation, it is reasonable to assume that petitions that end up with suspension agreements (i.e., formal agreements reached with the intermediation of ITA) correspond to industries with greater political influences and should have on average a higher level of employment. Data confirm this hypothesis: average employment for suspended petitions is 193.99 thousands, other withdrawn petitions have an average employment of 148.68 , and average employment for non withdrawn petitions is 95.46 .

\subsection{Results}

The results of four different specifications of the probit model defined in equation (9) are reported in Table 2. The sign next to each variable is what is expected from a theoretical standpoint. The first regression makes use of all the 588 observations and it gives a benchmark case for comparison to when some observations are dropped because of data problems. The use of disaggregate data improves the performance of the model and highlights interesting elements, as shown in the second column of Table 2. The two remaining columns present results for different specifications of coordination cost and macroeconomic effects.

The estimates in column (1) are in line with what is expected. Employment is significant and with the expected positive sign. Both variables related to the stock of filed petitions are statistically significant and with the expected signs, thus confirming the hypothesis of nonlinear effects in the bargaining power. Concentration, as represented by the number of companies, enters with the anticipated negative sign, though not statistically significant. Analogously, the dummy variable of an 
ad hoc committee filing a petition presents the expected positive sign, but it is not significant. ${ }^{17}$

The control variables are all statistically different from zero with the exception of the dummy variable for the steel sector. This is particularly important given that a large portion of withdrawn petitions pertains to the steel industry. It means that the phenomenon of withdrawing a petition is not necessarily sector specific, but can be explained by the general features captured by the other regressors. European Union and non market economies dummies are both positive. Moreover, non reported regressions where country dummies are included one at a time confirm the fact that countries of the European Union and non market economies are the only groups of countries whose dummy variables are significant.

The next step is to utilize disaggregate data. The use of information manually collected from reports published by ITC and ITA permits to better characterize the domestic industry and the foreign dumping producers; to my knowledge, this is the first paper that attempts such a disaggregated analysis. This source of information proves to be important in improving the performance of the estimated model even if it requires eliminating some observations. However, the next Section argues that this fact does not invalidate the results obtained.

The second column of Table 2 shows the results using data from these other sources. The conclusions reached before with respect to the bargaining power and the control variables are unchanged. Moreover, the characterization of domestic and foreign costs with disaggregate data gives interesting results. On the domestic side, the dummy variable for ad hoc committees filing a petition is now significant as well as the number of filers with the anticipated negative sign. Also the number of domestic firms enters with the expected sign but it is not significant. This is a relevant result: the number of filers is significant even after controlling for the number of firms. The variables for the foreign sector do not perform equally well. The number of foreign

\footnotetext{
${ }^{17}$ A dummy variable for a trade association filing a petition is not included because it turns out to be highly insignificant.
} 
firms enter with the expected negative sign, but it is not significant. The Herfindahl index, instead, does not present the predicted sign and is significant. This is a puzzling outcome and it is robust across various specifications.

A possible explanation for this result can be related to third markets. Assume that the exporters that are dumping in the United States are also exporting to other countries. If they collude with the US firms, they have to increase the price and reduce the quantity sold. In this case, the unsold quantity may be diverted to third markets. The increased sales in these markets can decrease the price in such a way that foreign producers are penalized so that they choose not to collude with the US industry. This outcome is more likely the more concentrated the foreign industry, assuming that concentrated foreign sectors signal large exporters to the third markets.

Column (3) investigates the relevance of the number of countries involved in a case. In general, it is believed that the more countries, the more likely an affirmative decision. For the present analysis, more countries may increase or decrease the cost of coordination to be inputted to each petition: the total cost of coordination is most probably increasing in the number of countries but there may be economies of scale. The square of the number of countries shows evidence of some form of nonlinearity: the probability of the petition being withdrawn initially increases with the number of countries, but declines with larger numbers of involved foreign countries. The qualitative results of the other regressors are virtually unchanged.

So far, all the regressions include the trade deficit and the nominal exchange rate, which are both significant, to control for the influence of the macroeconomic environment. A different strategy is to include dummy variables for each year. In this way, not only the macroeconomic effects are taken into account, but any other time effect is captured too. The last regression in Table 2 explores this possibility and the estimates are qualitatively the same.

The empirical analysis supports the conclusions of the theoretical model. A pattern for withdrawn petitions can be detected and related to 'bargaining power' and 
'coordination cost'. Then, the interpretation of withdrawn petitions as signals of collusive agreements between domestic and foreign industries is supported by the data. The analysis shows that the creation of an ad hoc committee to file the petition is a relevant element in order to facilitate the coordination task of domestic firms, while the more the filers, the more difficult it becomes to find a common strategy. The results for the foreign sectors are weaker: the number of foreign producers enters with the anticipated sign but it is never significant, while the concentration index does not enter in the way predicted by the theoretical model. The results for the bargaining power confirm that political pressure and some sort of reputation as represented by the number of filed petitions are important elements in the decision to withdraw.

At this point a clarification is necessary on the relationship between the results presented here and those reported by Staiger and Wolak (1994). They empirically distinguish three non-duty effects of a petition: investigation effect, suspension effect, and withdrawal effect, depending on the action being examined. They find clear evidence of the first two but not of the third. However, the definition of withdrawn petitions used in this paper includes what they refer to as suspension and withdrawal effect. Some petitions are withdrawn just because they are incomplete or do not satisfy the legal requirements. Eliminating these observations and not distinguishing between withdrawn and suspended petitions explains the apparent inconsistency between the results reported here and those of Staiger and Wolak.

\subsection{Sensitivity Analysis}

The aim of this Section is to check the robustness of the results presented in the previous Section. The focus is on two kind of concerns. First of all, the inclusion of disaggregate data implies dropping some observations because of missing data. In this respect, the regression in column (1) is estimated for the observations included in the other three columns. The qualitative results do not change.

Second, many different specifications can be constructed with the available vari- 
ables. It is therefore important to ascertain that it is not a particular choice of regressors that drives the results when different variables can represent the same effect. For this reason, many other regressions are considered with different variations for the domestic coordination cost, the bargaining power, and the control variables. Tables 3 and 4 report some of these trials with respect to modifications of the regression in column (2) of Table 2.

Table 3 documents possible alternative specifications of the domestic bargaining: cost. In column (1) and (2), exchanging the number of firms with the disaggregated Herfindahl index and the geographic concentration index Gamma does not modify the results. Column (3) and (4) include among the regressors two different principal factors which enter with the expected sign and are significant. ${ }^{18}$ In a set of non reported regression, the hypothesis that a large number of importers worsens the coordination problem is tested. The prediction is supported since the estimated coefficient is always negative though never significant across different specifications.

In Table 4, possible alternatives for the bargaining power and the control variables are investigated. In column (1), the square of employment captures nonlinear effects and there is some weak evidence in its favor: the square of employment is significant at $10 \%$ level but this result is not robust across specifications. The inclusion of the percentage change in employment and capacity utilization in column (2) follows from the idea that the larger the injury suffered by an industry, more likely its pressure for remedies will succeed. However, these regressors are not significant even if they present the anticipated sign.

The last two columns of Table 4 document a different way to characterize the macroeconomic environment. Specifically, in column (3) the percentage change in

\footnotetext{
${ }^{18}$ The predicted sign of a principal factor depends on the way the components of the factor enter in its definition. For the first principal factor, the numbers of filers and producers enter with a positive sign while the Herfindhal index enters with a negative sign. Therefore, larger values of the principal factor correspond to a less concentrated sector. The second principal factor is given by the number of companies, filers, and domestic firms that all enter with a negative sign, while VS4, the aggregate Herfindhal index, and the disaggregate Herfindhal index enter with a positive sign. Therefore, it should enter with a positive sign.
} 
the unemployment rate is used instead of the trade deficit and the nominal exchange rate while in column (4) the nominal exchange rate is also included. In the first case, unemployment is not significant but it becomes significant if the exchange rate is included: it looks as if some measure of the cycle is important but only if the effects of international relations are already captured. In fact, if the trade deficit is also included, the change in unemployment is no longer significant, since trade deficit and unemployment are both indicators of the business cycle (their correlation is -0.81), while the exchange rate is controlling for time variation only partially related to the business cycle (the correlation between exchange rate and percentage change in unemployment is -0.49$)$.

In the end, the conclusions reached in Section 4.2 are robust to different trials and specifications. However, a caveat must be kept in mind. There is a potential problem of self-selection in the petitions filed. In other words, it could be that only petitions that have good chances to win are actually filed and are then part of the sample. Even if there seems to be some evidence that runs against this bias (Finger and Murray, 1990; Prusa, 1991), recognizing this possibility implies that the interpretation of the results must be clearly related to the petitions that are actually filed.

\section{Conclusions}

This paper examines the possibility that AD petitions are used by domestic industries to threaten and induce foreign industries into a collusive arrangement. The motivation comes from the fact that many petitions filed with the ITC and the ITA for dumping cases are withdrawn before final conclusions are reached. This is just one side of the recent debate about $\mathrm{AD}$ laws and their true application. In particular, there is the suspicion that devices created for defensive reasons are now serving different purposes. The use of the petition as a credible threat hinges on the fact that if an agreement is not achieved, the investigation proceeds and duties are levied in case of 
an affirmative decision. Moreover, the Noerr-Pennington doctrine facilitates collusion at an international level since it provides an exemption to the antitrust law for US firms filing AD petitions.

This paper presents a model where the optimal choice between withdrawing a petition and waiting for the final determination depends on the coordination cost and bargaining power of the involved domestic and foreign industries. The combination of these two elements triggers the possibility of withdrawing the petition. This theoretical model improves upon previous studies, as Prusa (1992), in that it explicitly identifies the conditions necessary for withdrawing a petition. In particular, the model predicts that the probability to withdraw a petition is decreasing in the coordination costs and increasing with nonlinear effects in the bargaining power.

The theoretical model lends itself to an empirical appraisal. In this direction too, the present study improves upon previous findings by constructing a unique dataset with information collected from reports published by the ITC and the ITA. Making use of these disaggregate data as well as data from the US Census Bureau, the theoretical conclusions are tested on the US experience for the period 1980-1992. The empirical exercise provides support for the theoretical conclusions. Concentration indexes as measures of coordination cost and various indicators of bargaining power explain the choice to withdraw a petition. Therefore, the hypothesis that the antidumping law is used as a collusive device is supported by the data.

In conclusion, this paper highlights another aspect of the controversial application of $\mathrm{AD}$ laws. The fact that $\mathrm{AD}$ petitions seem to be used as collusive devices leads to the natural policy implication that a change of existing laws is needed. ${ }^{19}$ This change is necessary because agreements between domestic and foreign firms make possible at an international level what is forbidden at a national level by antitrust regulations. In other words, the policy implications of this paper are not different from what Adam Smith expressed in 1776 (page 144, italics added): "People of the same trade

\footnotetext{
${ }^{19}$ Proposals to change antidumping laws have already been made and based on many reasons. See, among others, Finger (1993, chapter 4) and Krishna (1997).
} 
seldom meet together, even for merriment and diversion, but the conversation ends in a conspiracy against the public, or in some contrivance to raise prices. It is impossible indeed to prevent such meetings, by any law which either could be executed, or would be consistent with liberty and justice. But though the law cannot hinder people of the same trade from sometimes assembling together, it ought to do nothing to facilitate such assemblies; much less to render them necessary." 


\section{Appendix A: Proofs}

\section{Proof of Lemma 1:}

- $\Pi_{D}^{*}<\Pi_{B}^{*}$ :

To show this, it is enough to prove that $Q_{D}^{*}<Q_{B}^{*}$ as illustrated in Figure A. In fact, $\Pi_{D}^{*}=\Pi\left(P_{D}^{*}, P_{D}\right)-d Q_{D}^{*}$ is smaller than $\Pi_{B}^{*}$ and it corresponds to the gray area for $Q^{*}<Q_{D}^{*}$ in the graph.

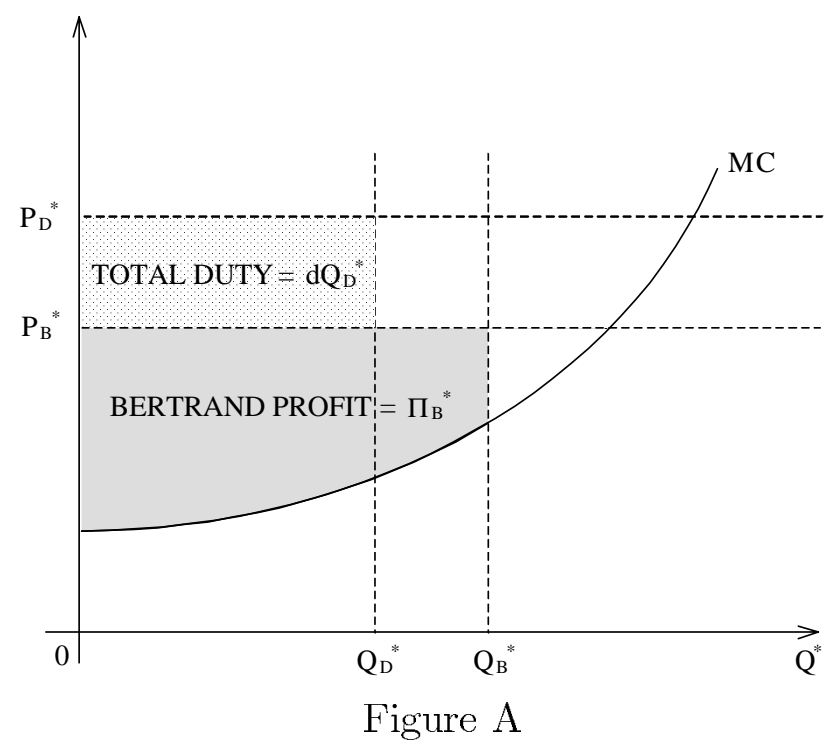

To prove that $Q_{D}^{*}<Q_{B}^{*}$, note that the conditions in footnote 8 implies

$$
\left.\sum_{h=1}^{n^{*}} \frac{\partial q_{j}^{*}\left(P^{*}, P\right)}{\partial p_{h}^{*}}\right|_{P=P_{B}, P^{*}=P_{B}^{*}}+\left.\sum_{k=1}^{n} \frac{\partial q_{j}^{*}\left(P^{*}, P\right)}{\partial p_{k}}\right|_{P=P_{B}, P^{*}=P_{B}^{*}}<0
$$

for each $j=1, \ldots, n^{*}$. Given the price $P_{D}^{*}$ imposed by the ITC, each domestic firm sets $p_{i D}$ according to its best response function. Since the slope of the best response function is less than one, the increase in the domestic price is smaller than the increase in the foreign price. Therefore, from (A1) the quantity sold by each foreign firm when duties are imposed is lower than in the Bertrand equilibrium, and the average at the industry level can only be lower as well.

- $\Pi_{D}>\Pi_{B}$ :

$\left(P_{D}, P_{D}^{*}\right)$ is a price combination strictly greater than $\left(P_{B}, P_{B}^{*}\right)$. Since $P_{D}$ is the best response to the price $P_{D}^{*}$ imposed by the ITC, the domestic industry is operating according to its best response function. This assures that $\Pi_{D}>\Pi_{B}$ since $P_{D}^{*}$ works as a coordinating device to set higher prices. 


\section{Proof of Proposition 1:}

The Nash bargaining game in (8) can be reformulated as follows:

$$
\max _{\Pi} \alpha \log \left[\Pi-\Pi^{e}(\rho)\right]+(1-\alpha) \log \left[g(\Pi)-\Pi^{* e}(\rho)\right] .
$$

It is possible to carry out the maximization in the profit space because of the one to one relationship between price combinations and profit combinations. Moreover, the functional form of the PPF permits to express $\Pi^{*}$ as a function of $\Pi$ : $\Pi^{*}=$ $g(\Pi) ; g^{\prime}(\cdot)<0, g^{\prime \prime}(\cdot)<0$.

The first order condition for the above problem is:

$$
\frac{\alpha}{\Pi-\Pi^{e}(\rho)}+\frac{(1-\alpha) g^{\prime}(\Pi)}{g(\Pi)-\Pi^{* e}(\rho)}=0 .
$$

The expression in (A3) implicitly defines the Nash bargaining solution for domestic profits $\Pi_{A}\left(P_{A}, P_{A}^{*}\right)$ and from the function $g(\cdot)$ it is possible to obtain the corresponding solution $\Pi_{A}^{*}\left(P_{A}, P_{A}^{*}\right)$ for foreign profits. Let $L(\Pi ; \alpha, \rho)$ be the implicit function defined in (A3). Making use of the implicit function theorem, partial derivatives can be computed and are as follows:

1. $\frac{\partial \Pi}{\partial \alpha}=-\frac{\frac{\partial L}{\partial \alpha}}{\frac{\partial L}{\partial \Pi}}=-\frac{\frac{1}{\Pi-\Pi^{e}}-\frac{g^{\prime}(\Pi)}{g(\Pi)-\Pi^{* e}}}{-\frac{\alpha}{\left(\Pi-\Pi^{e}\right)^{2}}-\frac{(1-\alpha) g^{\prime}(\Pi)^{2}}{\left[g(\Pi)-\Pi^{* e}\right]^{2}}+\frac{(1-\alpha) g^{\prime \prime}(\Pi)}{g(\Pi)-\Pi^{* e}}}>0$

2. $\frac{\partial \Pi^{*}}{\partial \alpha}=\frac{\partial g(\Pi)}{\partial \alpha}=g^{\prime}(\Pi) \cdot \frac{\partial \Pi}{\partial \alpha}<0 ;$

3. $\frac{\partial \Pi}{\partial \rho}=-\frac{\frac{\partial L}{\partial \rho}}{\frac{\partial L}{\partial \Pi}}=-\frac{\frac{\alpha \frac{\partial \Pi^{e}}{\partial \rho}}{\left[\Pi-\Pi^{e}\right]^{2}}-\frac{(1-\alpha) g^{\prime}(\Pi) \frac{\partial \Pi^{* e}}{\partial \rho}}{g(\Pi)-\Pi^{* e}}}{-\frac{\alpha}{\left(\Pi-\Pi^{e}\right)^{2}}-\frac{(1-\alpha) g^{\prime}(\Pi)^{2}}{\left[g(\Pi)-\Pi^{* e}\right]^{2}}+\frac{(1-\alpha) g^{\prime \prime}(\Pi)}{g(\Pi)-\Pi^{* e}}}>0 ;$

4. $\frac{\partial \Pi^{*}}{\partial \rho}=\frac{\partial g(\Pi)}{\partial \rho}=g^{\prime}(\Pi) \cdot \frac{\partial \Pi}{\partial \rho}<0$;

where $\frac{\partial \Pi^{e}}{\partial \rho}>0$ and $\frac{\partial \Pi^{* e}}{\partial \rho}<0$ from equations (5) and (6).

Let the critical values be

$$
\begin{gathered}
\widetilde{C}=\left\{C \mid \Pi\left(P_{A}, P_{A}^{*}\right)-C=\Pi^{e}\right\} \\
\widetilde{C}^{*}=\left\{C^{*} \mid \Pi^{*}\left(P_{A}, P_{A}^{*}\right)-C^{*}=\Pi^{* e}\right\} .
\end{gathered}
$$


If $C \leq \widetilde{C}$ and $C^{*} \leq \widetilde{C}^{*}$, both industries are better off under the agreement than under the ITC's decision; therefore the petitions is withdrawn. From the partial derivatives computed above, it follows that:

$$
\begin{gathered}
\left.\frac{\partial \widetilde{C}}{\partial \alpha}\right|_{\Pi_{=} \Pi_{A}}=\left.\frac{\partial \Pi}{\partial \alpha}\right|_{\Pi=\Pi_{A}}-\frac{\partial \Pi^{e}}{\partial \alpha}>0 \\
\left.\frac{\partial \widetilde{C}^{*}}{\partial \alpha}\right|_{\Pi^{*}=\Pi_{A}^{*}}=\left.\frac{\partial \Pi^{*}}{\partial \alpha}\right|_{\Pi^{*}=\Pi_{A}^{*}}-\frac{\partial \Pi^{* e}}{\partial \alpha}<0 \\
\left.\frac{\partial \widetilde{C}}{\partial \rho}\right|_{\Pi=\Pi_{A}}=\left.\frac{\partial \Pi}{\partial \rho}\right|_{\Pi=\Pi_{A}}-\frac{\partial \Pi^{e}}{\partial \rho} \gtrless 0 \\
\left.\frac{\partial \widetilde{C}^{*}}{\partial \rho}\right|_{\Pi^{*}=\Pi_{A}^{*}}=\left.\frac{\partial \Pi^{*}}{\partial \rho}\right|_{\Pi^{*}=\Pi_{A}^{*}}-\frac{\partial \Pi^{* e}}{\partial \rho} \lessgtr 0 .
\end{gathered}
$$

From equations (5) and (6), $\frac{\partial \Pi^{e}}{\partial \alpha}=\frac{\partial \Pi^{* e}}{\partial \alpha}=0$ and this justifies the signs in (A4) and $(A 5)$. The signs in (A6) and (A7) are ambiguous since they depend on first and second derivatives of the $g(\cdot)$ function and there are no possible simplifications of the terms.

\section{Appendix B: Data sources}

Basic petition information: petition number, year of filing, goods under investigation, outcome, and country involved have been derived from various issues of US International Trade Commission Annual Report and The Year in Trade: Operations of the Trade Agreements Program. The tariff code of the goods under investigation is found in the Federal Register.

SIC code: the four-digit code has been obtained by the TSUSA or HTS tariff code identifying the good under investigation. Concordances between categories obtained using Feenstra (1996).

The following variables have been manually collected from the ITC and ITA reports for each petition:

- Filers: number of US companies filing the petition.

- Domestic firms: number of US companies producing the good under investigation. 
- Domestic Herf. index: domestic Herfindahl-Hirshmann concentration index constructed using the number of firms and qualitative information about the structure of the market.

- Importers: number of US importers of the good under investigation.

- Foreign firms: number of foreign companies producing the good under investigation.

- Foreign Herf. index: foreign Herfindahl-Hirshmann concentration index constructed using the number of firms and qualitative information about the structure of the market.

- Countries: number of foreign countries involved in each case.

- Association: dummy variable that takes the value of 1 if the petition as been filed by a trade association.

- Ad hoc committee: dummy variable that takes the value of 1 if a committee has been formed in order to file the petition.

Petitions filed: stock of petitions filed by the industry (defined at 4-digit SIC level) from 1980 and up to each particular case.

Steel sector dummy: dummy variable for petitions filed by industry $3312,3321,3334$, $\overline{3339,3351,3357,34} 41,3494,3496,3519,3562$.

The following variables were obtained from different publications by the US Bureau of the Census and they all refer to 4-digit SIC data for the year when the petition was filed:

- Companies: number of companies obtained interpolating values available at a 5 -year frequency from the general census.

- Total employment: total employment in thousands of unit.

- Value of shipments of the 4 and 8 largest firms (VS4, VS8): percentage of shipments by the 4 and 8 largest firms in the industry obtained interpolating values available at a 5 -year frequency from the general census.

- Herfindahl-Hirshmann: Herfindahl-Hirshmann concentration index obtained interpolating values available at a 5-year frequency from the general census.

- Capacity utilization rate: percentage of capacity utilization obtained interpolating values available at a 5-year frequency from the general census. 
Geographic Gamma: geographic concentration index constructed by Ellison and Glaeser (1997); based on plant size distribution and employment per state.

Trade deficit: Imports - Exports; billions of chained 1992 dollars. From Economic Report of the President, 1999.

Nominal exchange rate: trade-weighted nominal exchange rate index against the currencies of the G-10 countries; March $1973=100$. From Economic Report of the President, 1999.

Capacity: percent of capacity utilization in manufacturing, from the Federal Reserve Board, Washington, D.C.

Unemployment: civilian unemployment rate, from the US Department of Labor Bureau of Economic Analysis.

Non market economies: dummy variable for petitions initiated against China, Czechoslovakia, East Germany, Hungary, Kazakhstan, Poland, Romania, Russia, Ukraine, USSR, Yugoslavia.

Developing countries: dummy variable for petitions initiated against Argentina, Bangladesh, Brazil, Chile, Colombia, Costa Rica, El Salvador, Hong Kong, India, Israel, Korea, Malaysia, Mexico, Philippines, Singapore, South Africa, Taiwan, Thailand, Trinidad/Tobago, Venezuela. 


\section{References}

[1] Anderson, J. E. (1992): "Domino dumping I: competitive exporters", American Economic Review 82, 65-83.

[2] Baldwin, R. E., Steagall, J. W. (1994): "An analysis of ITC decisions in antidumping, countervailing duty and safeguard cases", Weltwirtschaftliches Archiv $130,290-308$.

[3] DeVault, J. M. (1993): “The impact of the U.S. unfair trade laws: a preliminary assessment", Weltwirtschaftliches Archiv 129, 735-751.

[4] Ellison, G., Glaeser E. L. (1997): "Geographic concentration in U.S. manufacturing industries: a dartboard approach", Journal of Political Economy 105, 889-927.

[5] Feenstra, R. C. (1996): "U.S. imports, 1972-1994: data and concordances", NBER working paper 5515.

[6] Finger, M. J. editor (1993): Antidumping. How it works and who gets hurt. The University of Michigan Press, Ann Arbor.

[7] Finger, J. M., Hall, H. K., Nelson, D. R. (1982): "The political economy of administered protection", American Economic Review 72, 452-466.

[8] Finger, J. M., Murray, T. (1990): "Policing unfair imports: the United States example", Journal of World Trade 2/4, 39-53.

[9] Friedman, J. W. (1977): Oligopoly and the theory of games, North-Holland Publishing Company.

[10] Gallaway, M.C., Blonigen, B.A., Flynn, J. E. (1999): "Welfare costs of the U.S. antidumping and countervailing duty laws", Journal of International Economics $49,211-244$. 
[11] Hansen, W. L., Prusa, T. J. (1996): "Cumulation and ITC decision-making: the sum of the parts is greater than the whole", Economic Inquiry XXXIV, 746-769.

[12] Krishna, R. (1997): "Antidumping in law and practice", World Bank Policy Research Working Paper 1823.

[13] Nash, J. (1950): “The bargaining problem", Econometrica 18, 155-162.

[14] Ottaviano, G. I. P., Thisse, J. F. (1999): "Monopolistic competition, multiproduct firms and optimum product diversity", CORE Discussion Paper 9919.

[15] Prusa, T. J. (1991): "The selection of antidumping cases for ITC determination", in Baldwin, R. E. editor: Empirical studies in commercial policy. The University of Chicago Press, Chicago and London.

[16] Prusa, T. J. (1992): "Why are so many antidumping petitions withdrawn?", Journal of International Economics 33, 1-20.

[17] Rubinstein, A (1982): "Perfect Equilibrium in a Bargaining Model", Econometrica 50, 97-109.

[18] Shelburne R., Bednarzik R. (1992): "The geographical concentration of employment and its implications for trade and adjustment", working paper, U.S. Department of Labor - Bureau of International Labor Affairs.

[19] Smith, A. (1776): An inquiry into the nature and causes of the wealth of nations. Edited by Cannan E., The University of Chicago Press, 1976.

[20] Staiger, R. W., Wolak, F. A. (1989): "Strategic use of antidumping law to enforce tacit international collusion", NBER working paper 3016.

[21] Staiger, R. W., Wolak, F. A. (1994): "Measuring industry-specific protection: antidumping in the United States", Brookings Papers on Microeconomics, 51118. 
[22] U.S. International Trade Commission (various years): Annual report. Washington DC.

[23] U.S. International Trade Commission (various years): The year in trade: operations of the trade agreements program. Washington DC.

[24] Veugelers, R., Vandenbussche, H. (1999): "European anti-dumping policy and the profitability of national and international collusion", European Economic Review 43, 1-28. 


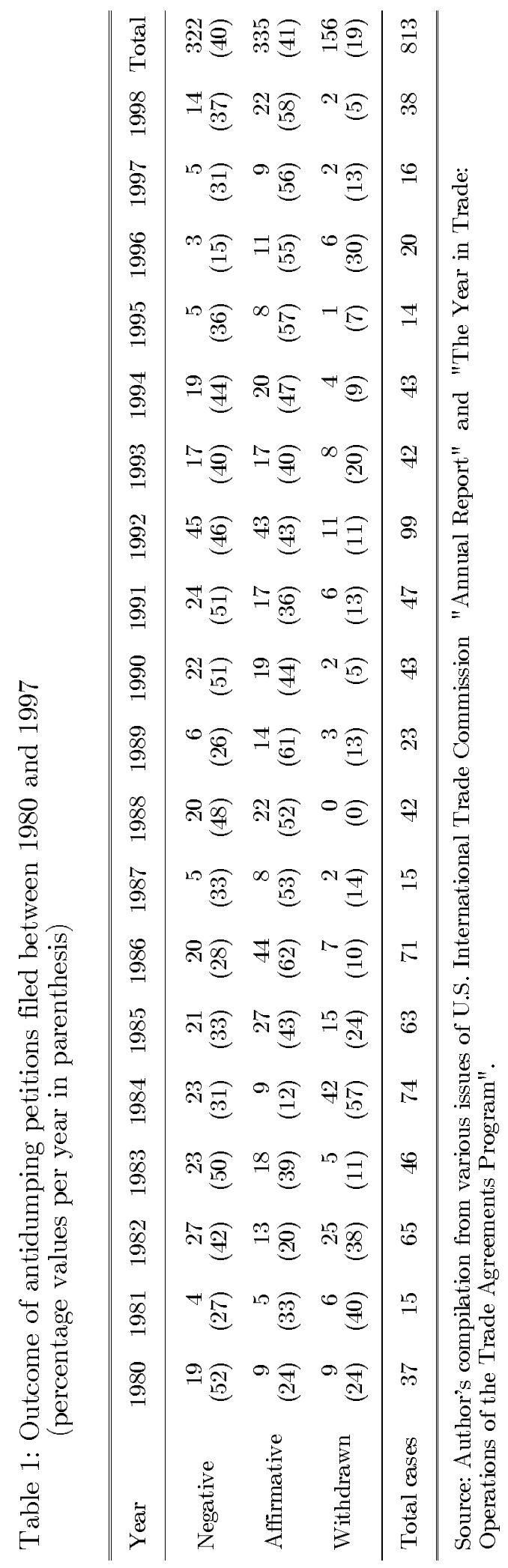


Table 2: Main specifications

\begin{tabular}{|c|c|c|c|c|c|}
\hline & Regressors & $(1)$ & $(2)$ & (3) & $(4)$ \\
\hline \multirow[t]{6}{*}{ Domestic Cost } & Adhoc comm. $(+)$ & $\begin{array}{l}.221 \\
(.447)\end{array}$ & $\begin{array}{c}1.206^{* *} \\
(.497)\end{array}$ & $\begin{array}{l}1.230^{* *} \\
(.484)\end{array}$ & $\begin{array}{l}.963^{* *} \\
(.491)\end{array}$ \\
\hline & Companies (-) & $\begin{array}{l}-.0003 \\
(.0002)\end{array}$ & & & \\
\hline & Filers (-) & & $\begin{array}{c}-.066^{* *} \\
(.028)\end{array}$ & $\begin{array}{c}-.077^{* * *} \\
\quad(.028)\end{array}$ & $\begin{array}{l}-.056^{*} \\
(.031)\end{array}$ \\
\hline & Domest. firms (-) & & $\begin{array}{l}-.005 \\
(.006)\end{array}$ & & $\begin{array}{l}-.009 \\
(.007)\end{array}$ \\
\hline & Countries $(+)$ & & & $\begin{array}{c}.340^{* * *} \\
(.131)\end{array}$ & \\
\hline & Countries $^{2}(+)$ & & & $\begin{array}{c}-.031^{* *} \\
(.012)\end{array}$ & \\
\hline \multirow[t]{2}{*}{ Foreign Cost } & Foreign firms (-) & & $\begin{array}{l}-.021 \\
(.026)\end{array}$ & $\begin{array}{l}-.021 \\
(.026)\end{array}$ & $\begin{array}{l}-.012 \\
(.027)\end{array}$ \\
\hline & Foreign Herf. $(+)$ & & $\begin{array}{c}-.709^{* *} \\
(.300)\end{array}$ & $\begin{array}{c}-.688^{* *} \\
(.302)\end{array}$ & $\begin{array}{c}-.763^{* *} \\
(.316)\end{array}$ \\
\hline \multirow[t]{3}{*}{ Bargaining Power } & Employment $(+)$ & $\begin{array}{l}.005^{* * *} \\
(.001)\end{array}$ & $\begin{array}{c}.006^{* * *} \\
(.001)\end{array}$ & $\begin{array}{c}.006^{* * *} \\
(.001)\end{array}$ & $\begin{array}{c}.006^{* * *} \\
(.001)\end{array}$ \\
\hline & Petit. filed $(+)$ & $\begin{array}{c}.088^{* * *} \\
(.026)\end{array}$ & $\begin{array}{c}.101^{* * * *} \\
(.030)\end{array}$ & $\begin{array}{c}.100^{* * *} \\
(.030)\end{array}$ & $\begin{array}{l}.154^{* * * *} \\
(.052)\end{array}$ \\
\hline & Petit. filed ${ }^{2}(-)$ & $\begin{array}{c}-.003^{* * *} \\
(.0006)\end{array}$ & $\begin{array}{c}-.003^{* * *} \\
(.001)\end{array}$ & $\begin{array}{c}-.003^{* * *} \\
(.001)\end{array}$ & $\begin{array}{c}-.004^{* * *} \\
(.001)\end{array}$ \\
\hline \multirow[t]{11}{*}{ Control Variables } & EU dummy & $\begin{array}{l}.499^{* *} \\
(.197)\end{array}$ & $\begin{array}{c}.864^{* * * *} \\
(.248)\end{array}$ & $\begin{array}{l}.755^{* *} \\
(.278)\end{array}$ & $\begin{array}{c}.866^{* * *} \\
(.264)\end{array}$ \\
\hline & Nonma. dummy & $\begin{array}{l}.477^{* *} \\
(.192)\end{array}$ & $\begin{array}{c}.637^{* * *} \\
(.237)\end{array}$ & $\begin{array}{c}.619^{* * *} \\
(.242)\end{array}$ & $\begin{array}{l}.607^{* *} \\
(.236)\end{array}$ \\
\hline & Steel dummy & $\begin{array}{l}-.153 \\
(.198)\end{array}$ & $\begin{array}{l}.313 \\
(.300)\end{array}$ & $\begin{array}{l}.189 \\
(.297)\end{array}$ & $\begin{array}{l}.131 \\
(.324)\end{array}$ \\
\hline & Cumul. dummy & $\begin{array}{c}1.290^{* * *} \\
(.358)\end{array}$ & $\begin{array}{l}1.454^{* *} \\
(.478)\end{array}$ & $\begin{array}{c}1.673^{* * *} \\
(.529)\end{array}$ & \\
\hline & Trade deficit & $\begin{aligned}-.008^{* * *} \\
(.003)\end{aligned}$ & $\begin{array}{c}-.010^{* *} \\
(.004)\end{array}$ & $\begin{aligned}-.013^{* * *} \\
(.004)\end{aligned}$ & \\
\hline & Nom. exch. rate & $\begin{array}{c}.022^{* * *} \\
(.007)\end{array}$ & $\begin{array}{c}.030^{* * *} \\
(.008)\end{array}$ & $\begin{array}{c}.033^{* * *} \\
(.009)\end{array}$ & \\
\hline & Year dummies & Not incl. & Not incl. & Not incl. & Includ. \\
\hline & Observations & 588 & 533 & 533 & 393 \\
\hline & Log likelihood & -192.68 & -133.59 & -129.98 & -125.73 \\
\hline & Pseudo $\mathrm{R}^{2}$ & .33 & .46 & .48 & .42 \\
\hline & $\chi^{2}$ & $120.77^{* * *}$ & $125.21^{* * *}$ & $111.10^{* * *}$ & $112.53^{* * *}$ \\
\hline
\end{tabular}

* denotes significance at the $10 \%$ level; ** 5\% level; and *** $1 \%$ level.

Robust standard errors in parenthesis. Constant included. 
Table 3: Sensitivity analysis - coordination cost

\begin{tabular}{|c|c|c|c|c|c|}
\hline & Regressors & $(1)$ & $(2)$ & $(3)$ & $(4)$ \\
\hline \multirow[t]{6}{*}{ Domestic Cost } & Adhoc comm. $(+)$ & $\begin{array}{c}1.188^{* *} \\
(.517)\end{array}$ & $\begin{array}{c}1.409^{* * *} \\
(.518)\end{array}$ & $\begin{array}{c}1.236^{* *} \\
(.518)\end{array}$ & $\begin{array}{c}1.245^{* *} \\
(.524)\end{array}$ \\
\hline & Filers (-) & $\begin{array}{l}-.069^{* *} \\
(.028)\end{array}$ & $\begin{array}{l}-.077^{*} \\
(.028)\end{array}$ & & \\
\hline & Domestic Herf. (+) & $\begin{array}{l}.241 \\
(.461)\end{array}$ & & & \\
\hline & Gamma index $(+)$ & & $\begin{array}{l}5.371 \\
(3.381)\end{array}$ & & \\
\hline & PC disagg. var. (-) & & & $\begin{array}{l}-.235^{* *} \\
(.096)\end{array}$ & \\
\hline & PC all var. $(+)$ & & & & $\begin{array}{l}.219^{* * *} \\
(.079)\end{array}$ \\
\hline \multirow[t]{2}{*}{ Foreign Cost } & Foreign firms (-) & $\begin{array}{l}-.020 \\
(.025)\end{array}$ & $\begin{array}{l}-.016 \\
(.024)\end{array}$ & $\begin{array}{l}-. .014 \\
(.024)\end{array}$ & $\begin{array}{l}-.014 \\
(.023)\end{array}$ \\
\hline & Foreign Herf. $(+)$ & $\begin{array}{c}-.712^{* *} \\
(.300)\end{array}$ & $\begin{array}{c}-.653^{* *} \\
(.304)\end{array}$ & $\begin{array}{l}-.651^{* *} \\
(.292)\end{array}$ & $\begin{array}{l}-.660^{* *} \\
(.285)\end{array}$ \\
\hline \multirow[t]{3}{*}{ Bargaining Power } & Employment $(+)$ & $\begin{array}{l}.006^{* * *} \\
(.001)\end{array}$ & $\begin{array}{l}.006^{* * *} \\
(.001)\end{array}$ & $\begin{array}{l}.006^{* * *} \\
(.001)\end{array}$ & $\begin{array}{l}.006^{* * *} \\
(.001)\end{array}$ \\
\hline & Petit. filed $(+)$ & $\begin{array}{l}.101^{* * *} \\
(.030)\end{array}$ & $\begin{array}{l}.076^{* *} \\
(.032)\end{array}$ & $\begin{array}{l}.104^{* * *} \\
(.029)\end{array}$ & $\begin{array}{l}.107^{* * *} \\
(.030)\end{array}$ \\
\hline & Petit. filed $^{2}(-)$ & $\begin{array}{c}-.003^{* * *} \\
(.001)\end{array}$ & $\begin{array}{c}-.003^{* * *} \\
(.001)\end{array}$ & $\begin{array}{c}-.003^{* * *} \\
(.001)\end{array}$ & $\begin{array}{l}-.003^{* * *} \\
(.001) \\
\end{array}$ \\
\hline \multirow[t]{10}{*}{ Control Variables } & EU dummy & $\begin{array}{l}.874^{* * *} \\
(.244)\end{array}$ & $\begin{array}{l}.853^{* * *} \\
(.258)\end{array}$ & $\begin{array}{l}.827^{* * *} \\
(.244)\end{array}$ & $\begin{array}{l}.838^{* * * *} \\
(.247)\end{array}$ \\
\hline & Nonma. dummy & $\begin{array}{l}.638^{* * *} \\
(.236)\end{array}$ & $\begin{array}{l}.651^{* * *} \\
(.247)\end{array}$ & $\begin{array}{l}.602^{* * *} \\
(.232)\end{array}$ & $\begin{array}{l}.626^{* * *} \\
(.234)\end{array}$ \\
\hline & Steel dummy & $\begin{array}{l}.325 \\
(.338)\end{array}$ & $\begin{array}{l}.288 \\
(.304)\end{array}$ & $\begin{array}{l}.436 \\
(.335)\end{array}$ & $\begin{array}{c}.418 \\
(.319)\end{array}$ \\
\hline & Cumul. dummy & $\begin{array}{l}1.459^{* * *} \\
(.483)\end{array}$ & $\begin{array}{l}1.761^{* * *} \\
(.461)\end{array}$ & $\begin{array}{l}1.494^{* * *} \\
(.487)\end{array}$ & $\begin{array}{c}1.447^{* * *} \\
(.464)\end{array}$ \\
\hline & Trade deficit & $\begin{array}{l}-.010^{* *} \\
(.004)\end{array}$ & $\begin{array}{l}-.011^{* *} \\
(.004)\end{array}$ & $\begin{array}{l}-.010^{* *} \\
(.004)\end{array}$ & $\begin{array}{l}-.010^{* *} \\
(.004)\end{array}$ \\
\hline & Nom. exch. rate & $\begin{array}{c}.030^{* * *} \\
(.008) \\
\end{array}$ & $\begin{array}{c}.036^{\text {*** }} \\
(.009) \\
\end{array}$ & $\begin{array}{c}.027^{* * *} \\
(.008) \\
\end{array}$ & $\begin{array}{c}.028^{* * * *} \\
(.008) \\
\end{array}$ \\
\hline & Observations & 533 & 504 & 533 & 533 \\
\hline & Log likelihood & -133.70 & -126.00 & -134.36 & -133.93 \\
\hline & Pseudo $\mathrm{R}^{2}$ & .46 & .48 & .46 & .46 \\
\hline & $\chi^{2}$ & $120.39^{* * *}$ & $124.18^{* * *}$ & $121.33^{* * *}$ & $129.48^{* * *}$ \\
\hline
\end{tabular}

* denotes significance at the $10 \%$ level; ** $5 \%$ level; and *** $1 \%$ level.

Robust standard errors in parenthesis. Constant included. 
Table 4: Sensitivity analysis - bargaining power and macro effects

\begin{tabular}{|c|c|c|c|c|c|}
\hline & Regressors & (1) & $(2)$ & $(3)$ & (4) \\
\hline \multirow[t]{3}{*}{ Domestic Cost } & Adhoc comm. $(+)$ & $\begin{array}{c}1.367^{* * *} \\
(.520)\end{array}$ & $\begin{array}{l}1.173^{* *} \\
(.519)\end{array}$ & $\begin{array}{l}.960^{* *} \\
(.480)\end{array}$ & $\begin{array}{l}1.005^{* *} \\
(.485)\end{array}$ \\
\hline & Filers (-) & $\begin{array}{l}-.079^{* * *} \\
(.030)\end{array}$ & $\begin{array}{c}-.077^{* *} \\
(.032)\end{array}$ & $\begin{aligned}-.046^{*} \\
(.027)\end{aligned}$ & $\begin{array}{l}-.082^{* * *} \\
(.030)\end{array}$ \\
\hline & Domest. firms (-) & $\begin{array}{l}-.005 \\
(.006)\end{array}$ & $\begin{array}{l}-.003 \\
(.007)\end{array}$ & $\begin{array}{l}-.001 \\
(.019)\end{array}$ & $\begin{array}{l}-.005 \\
(.006)\end{array}$ \\
\hline \multirow[t]{4}{*}{ Foreign Cost } & Foreign firms (-) & $\begin{array}{l}-.018 \\
(.026)\end{array}$ & $\begin{array}{l}-.020 \\
(.027)\end{array}$ & $\begin{array}{l}-.012 \\
(.027)\end{array}$ & $\begin{array}{l}-.008 \\
(.024)\end{array}$ \\
\hline & Foreign Herf. $(+)$ & $\begin{array}{c}-.683^{* *} \\
(.305)\end{array}$ & $\begin{array}{c}-.650^{* *} \\
(.306)\end{array}$ & $\begin{array}{l}-.522^{*} \\
(.286)\end{array}$ & $\begin{array}{c}-.671^{* *} \\
(.300)\end{array}$ \\
\hline & Employment $(+)$ & $\begin{array}{c}.013^{* * *} \\
(.004)\end{array}$ & $\begin{array}{l}.006^{* * *} \\
(.001)\end{array}$ & $\begin{array}{c}.006^{* * *} \\
(.001)\end{array}$ & $\begin{array}{l}.006^{* * *} \\
(.001)\end{array}$ \\
\hline & Employment $^{2}(-)$ & $\begin{array}{c}-.00002^{*} \\
(8.94 e-06)\end{array}$ & & & \\
\hline \multirow[t]{4}{*}{ Bargaining Power } & $\% \Delta \mathrm{Empl}_{t, t-1}(-)$ & & $\begin{array}{l}-.252 \\
(.988)\end{array}$ & & \\
\hline & $\% \Delta \mathrm{Capa}_{t, t-1}(-)$ & & $\begin{array}{l}-.401 \\
(.586)\end{array}$ & & \\
\hline & Petit. filed $(+)$ & $\begin{array}{l}.074^{* *} \\
(.032)\end{array}$ & $\begin{array}{c}.109^{* * *} \\
(.034)\end{array}$ & $\begin{array}{c}.157^{* * *} \\
(.032)\end{array}$ & $\begin{array}{c}.145^{* * *} \\
(.035)\end{array}$ \\
\hline & Petit. filed ${ }^{2}(-)$ & $\begin{array}{c}-.002^{* * *} \\
(.0007)\end{array}$ & $\begin{array}{l}-.003^{* * *} \\
\quad(.001)\end{array}$ & $\begin{array}{l}-.004^{* * *} \\
(.001)\end{array}$ & $\begin{array}{l}-.004^{* * *} \\
(.001)\end{array}$ \\
\hline \multirow[t]{11}{*}{ Control Variables } & EU dummy & $\begin{array}{l}.834^{* *} \\
(.254)\end{array}$ & $\begin{array}{l}.822^{* * *} \\
(.257)\end{array}$ & $\begin{array}{l}.766^{* * *} \\
(.234)\end{array}$ & $\begin{array}{l}.823^{* * *} \\
(.245)\end{array}$ \\
\hline & Nonma. dummy & $\begin{array}{c}.690^{* * *} \\
(.245)\end{array}$ & $\begin{array}{l}.580^{* *} \\
(.239)\end{array}$ & $\begin{array}{l}.646^{* *} \\
(.235)\end{array}$ & $\begin{array}{l}.670^{* * *} \\
(.235)\end{array}$ \\
\hline & Steel dummy & $\begin{array}{l}.329 \\
(.297)\end{array}$ & $\begin{array}{l}.157 \\
(.303)\end{array}$ & $\begin{array}{l}.356 \\
(.298)\end{array}$ & $\begin{array}{l}.155 \\
(.292)\end{array}$ \\
\hline & Cumul. dummy & $\begin{array}{c}1.601^{* * *} \\
(.450)\end{array}$ & $\begin{array}{c}1.287^{* *} \\
(.576)\end{array}$ & $\begin{array}{l}.952^{* *} \\
(.475)\end{array}$ & $\begin{array}{c}1.206^{* *} \\
(.478)\end{array}$ \\
\hline & Trade deficit & $\begin{array}{c}-.010^{* *} \\
(.004)\end{array}$ & $\begin{array}{l}-.009^{*} \\
(.005)\end{array}$ & & \\
\hline & Nom. exch. rate & $\begin{array}{c}.028^{* * *} \\
(.008)\end{array}$ & $\begin{array}{c}.026^{* * *} \\
(.010)\end{array}$ & & $\begin{array}{l}.022^{* * *} \\
(.005)\end{array}$ \\
\hline & $\% \Delta$ Unempl. $_{\text {rate }}, t-1$ & & & $\begin{array}{l}1.021 \\
(.948)\end{array}$ & $\begin{array}{l}2.601^{* * *} \\
(1.078)\end{array}$ \\
\hline & Observations & 533 & 515 & 533 & 533 \\
\hline & Log likelihood & -131.71 & -129.15 & -138.82 & -133.64 \\
\hline & Pseudo $\mathrm{R}^{2}$ & .47 & .46 & .44 & .46 \\
\hline & $\chi^{2}$ & $134.57^{* * *}$ & $133.50^{* * *}$ & $133.16^{* * *}$ & $127.00^{* * *}$ \\
\hline
\end{tabular}

$*$ denotes significance at the $10 \%$ level; $* * 5 \%$ level; and $* * * 1 \%$ level.

Robust standard errors in parenthesis. Constant included. 